\title{
Will Saudi's 2030 Vision Raise the Students' Awareness to National Literature? Saudi Literature and Identity
}

\author{
${ }^{1}$ Mubarak Altwaiji, ${ }^{2}$ Majed Alenezi, ${ }^{3}$ Sajeena Gayathrri, ${ }^{4}$ Ebrahim Mohammed Alwuraafi, \\ ${ }^{5}$ Maryam Naif Alanazi \\ ${ }^{1}$ Head of English Language Skills Department, Northern Border University, Kingdom of Saudi Arabia. \\ ORCID ID: https://orcid.org/0000-0001-8927-4494 \\ ${ }^{2}$ English Language and Translation Department, Northern Border University, Kingdom of Saudi Arabia. \\ ${ }^{13}$ English Language Skills Department, Northern Border University, Kingdom of Saudi Arabia. \\ ${ }^{4}$ Department of English Language and Literature, Albaha University, Kingdom of Saudi Arabia. \\ ${ }^{5}$ English Instructor, Northern Border University, Kingdom of Saudi Arabia.
}

Received: March 28, 2021. Revised: May 7, 2021. Accepted: May 10, 2021. Published: May 17, 2021.

\begin{abstract}
Forming national identity is placed on top of the seven aspects of High-Impact Educational Practices (HIEPs) in Northern Border University. Similarly, the concept of academic awareness to national literature has been one of the main challenges to national literature in the Middle East. Just as the strong presence of national identity in Saudi's 2030 vision has initiated re-evaluations of how national identity is shaped, Saudi novel has similar concerns that inform social constructs of national identity through overarching themes and comprehensive representations of cultural issues. This study investigates the ways in which two Saudi novelists interrogate the intertwined issues shared by 2030 vision and national novel which address the archetypal Saudi identity: first, that the construction of modern identity requires much cultural openness with the world; second, that construction of Saudi identity needs exclusion of otherness; and third, that national identity depends on the rich history of two historical regions - Najd and Hijaz - that binds identity to a unified territory. The study focuses on how these novels give visibility to issues that are at the core of 2030 vision's social and cultural aspect such as life style, appearance behaviours, attitudes, accepting differences and willingness to work and volunteer. Drawing on this narrative analysis, the study advocates for the utility of introducing national novel for undergraduate students to help them perceive identity as a position and support their identity enactment.
\end{abstract}

Keywords-national identity, Saudi novel, society, students

\section{INTRODUCTION AND BACKGROUND}

On 25 April 2016 Prince Mohammed bin Salman announced the State's Vision 2030 (The National Transformation Programme) offering a great deal of national reforms and ensuring the widespread recognition of individual contribution to national development: "We are returning to what we were before - a country of moderate Islam that is open to all religions and to the world...We will not spend the next 30 years of our lives dealing with destructive ideas" (Akeel, 2017). Since 2016 the Vision 2030 has been the most prominent social and cultural portfolio in the Kingdom that built Prince Mohammed's reputation and widespread admiration among the citizens. The cultural aspect of the Vision 2030 designed to enhance the influence of culture and move the society away from radically-fostered thoughts creating a strong schism between conservative thoughts and the people in a very short time. He created Ministry of Culture for the first time in the history of the state.

At the heart of our vision is a society in which all enjoy a good quality of life, a healthy lifestyle, and an attractive living environment. Our goal is to promote and reinvigorate social 
development in order to build a strong and productive society. We consider culture and entertainment indispensable to our quality of life...It is why we will support the efforts of regions, governorates, non-profit and private sectors to organize cultural events... We will seek to offer a variety of cultural venues - such as libraries, arts and museums - as well as entertainment possibilities to suit tastes and preferences. (Vision 2030, 2016)

In 2007, the Saudi anthropologist Madawi al-Rasheed defined the Kingdom of Saudi Arabia as "a state that is politically secular and socially religious" (p. 57). The de facto trends and structure of Saudi literature, al-Rasheed argues, cannot be separated from religion as the 'ulama' council (religious scholars) has full control over the social practices and the people's lifestyle, limiting the political institution to run the country's economy and external affairs: "The gap between the social sphere controlled by religious scholars and the political sphere controlled by royalty is responsible for serious contradictions experienced at the level of the individual and society" (p. 58). Therefore, the 'conservative' or 'theocratic unitarian' terminologies used by several critics to describe the state are inappropriate. In this introductory part, the study focuses on how Saudi novel grew and represented social issues under this officially-protected union.

Literary attention dedicated to 'national identity' in the context of social transformation captures an early stage in Saudi novel (Altwaiji, 2017, p. 163). Saudi writers had been vocal in addressing national identity and denouncing terrorist acts and aggression, providing a counter-discourse to the western perceptions that Arabs are terrorists (Alharthi, 2015, p. 70). The question of identity is addressed through three themes of national spirit, social freedom, and gender for which novelists struggle to maintain a convergence of identity trends: national identity, Arab identity, and Islamic identity (Altwaiji $\&$ Muna, 2020, p. 320). However, the major challenge to narrative reality of the Kingdom has long been the restrictive practices of the religious authority - to be distinguished from the political establishment that has a considerable liberal margin - that aimed "at stopping the publication or distribution of content deemed politically, morally, or religiously sensitive" (Schwartz, et al. 2009, p.4). These restrictions have profoundly affected the performance of writers and have also posed serious challenges to the development of national narrative.

Saudi novelists have always been from a relatively welleducated background and have actively introduced social issues and ideas in narratives, challenging the religious authority and often arousing its wrath. While these novelists were trying to represent national identity and major national issues in fiction, there were several instances whereby religious scholar criticized them and label them as kufar (apostates), mulhideen (atheists) and almanyoon (secularists). Prominent novelists like Ghazi al-Qusaybi, Abdulrahman
Munif, Abdullah al-Qasimi, and Turki al-Hamad who first addressed national identity were criticized by religious figures for adapting liberal language which does not suit a Muslim reader (Al-Rasheed, 2007, p. 40). These writers were excommunicated and forced to live abroad under the patronage of senior Saudi princes. This complex context of Saudi novelists' interest in identity issues is important for understanding not only the development of these issues in narrative work but also the international context in which Saudi identity is perceived and represented.

The relationship between religion and the political regime has remained pretty pleasant and fluid for decades in Saudi Arabia. This greater convergence of religious ordinances and states' politics provides "the dominance and superiority of the state religion" and the "national security policies" in several countries including many Eastern European countries (BarMaoz, 2018, p. 39). This has been especially true in Saudi Arabia in which policymakers institutionalized the involvement of the religious foundation in domestic priorities and decision-making. However, this strategic relationship witnessed a dramatic change with the coming of Crown Prince Mohammed bin Salman who challenged the religious authority and ended its partnership with the state describing it as "not normal" and that does not fit into Saudi socio-cultural reforms he is leading (Chulov, 2017). He promises to destroy the state's relationship with the religious entity and return the country to normality: "Now is the time to get rid of it...[H]onestly we won't waste 30 years of our life combating extremist thoughts, we will destroy them now and immediately" (2017). The authority of MBS gave impetus for liberal thoughts of the young generation who were pleased that the Prince 'spoke their minds' and targeted the greatest challenges facing the modern state.

Several Saudi critics of the social construct have been blaming the pre-2030 vision's dominant religious-based system for suppressing the liberal voices and engendering the phenomena of Islamist revivalism, extremism and moral/epistemological relativism (Thompson, 2017 a; Thompson, 2017 b; Jawadi et al., 2018; Cochran, 2019; Aboalshamat, 2020). Similarly, the novels of liberal voices are officially banned because these writers break the taboos by criticizing socio-cultural issues of oppression, women's sexuality, and discrimination against women or targeting influential religious lobbies and clergymen. Despite the fact that several novels were banned, they succeeded in attracting a broad readership in regional and international marketplace, following their translation into English and French (Algahtani, 2016). The selected novels for this study are three. The study employs the principles of deductive research by putting these novels on par with world narratives that have the same concerns about identity, extremist thoughts and human rights.

However, several factors such as the rapid oil-based economic growth, the two gulf wars, the 9/11 terrorist attacks, the advent of technology and the recent major social reforms have played significant roles in the formation of national novel 
and inspired the people to "write, share and publish works and ideas" and "engage in political participation in Saudi Arabia, spreading ideas about human rights and freedom of expression" (Algahtani, 2016, p. 27). These factors provided opportunities for Saudi writers to represent several issues in a much broader freedom than they have experienced before and allowed them to deal with some cultural sensitive issues. Abdo Khal whose novel Spewing Sparks is banned in the Kingdom says that lifting the ban on Al-Gosaibi's novels will pave the way for several novels to be allowed inside the country: "My books and all other banned books are like migrating birds. These books are written for a local audience" (Sidiya, 2010). As evidenced in the significant rise in the number of published novels, the social reforms and the widespread of technology in the country have facilitated discussions in virtual space and encouraged dissemination of novels.

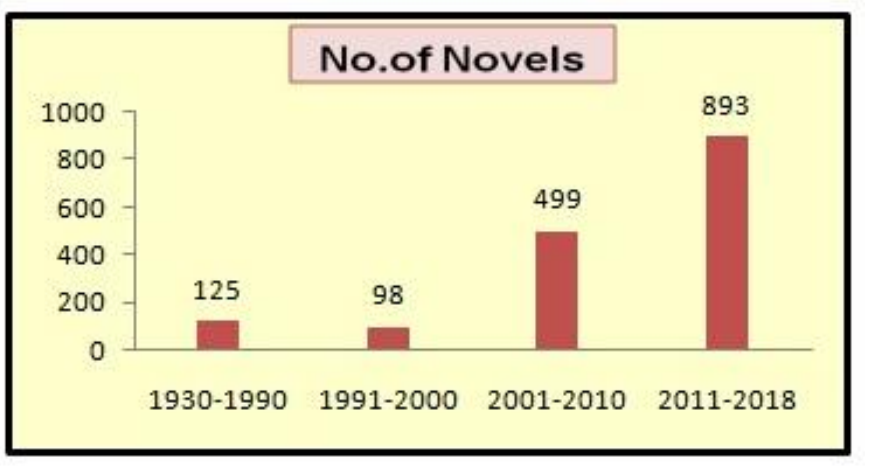

Fig. 1. The publication of Saudi novel 1930-2018.

Saudi novel has been the best aesthetic manifestation of identity reforms that questions the canonical assumption that national identity is the outgrowth of fixed beliefs in the institution of Islamic theology. This significant surge was first witnessed in women novelists in 1980s and 1990s in which educated women novelists developed a deeper critique of the religious measures against women's education and higher degree of mobility inside the country: "the voices of women all combine to boost state legitimacy at a critical moment in its quest for new recognition" (Al-Rasheed, 2013, p. 209). The common trend in these works is their critique of religious institution and its practices which has a profound effect on the public: 'It has to do with their 'perception' of their conservative society's reception of the potentially unsettling 'alternative intentions' of novels that deal with sensitive issues in that society" (Shboul, 2007, p.204). Amal Shata, Samira Khashugji, Raja Alem and Huda al-Rashid are the pioneer of women's novel and its liberal voice that emerged outside the country "when the dominant patriarchal cultural and social context was not conducive to the emergence of female novelists" (Algahtani, 2016, p. 27). From the early 2000s women novelists have been exerting considerable national and international pressure on the state to change the maledominated attitudes and perceptions about the female:

In this respect, women novelists and literary figures do not create their own agendas but are co-opted into political projects that are set up by more powerful agents in society, from individual kings and princes to media institutions, education, and dialogue forums. They hope that their enlistment will eventually lead to women gaining more rights and enjoying fewer restrictions in their own social, personal, and professional lives.

(Al-Rasheed, 2013, p. 210-218)

One of the main objectives of this study is to highlight the growing cohort of women novelists' success in forming contemporary Saudi identity from a liberal perspective. By a liberal perspective, the authors mean how women novelists represent female characters from a secularist and anti-theist and "reducing religion to a kind of medieval form of knowledge; or considering religion to be against the emancipation of mind and gender relations; or regarding it as an instrument for oppressing the society" (Kanie, 2017, p. 284). This major transformation in narrative reality implies a profound effect on both national identity and national novel in the country. In this phase, a new generation of women novelists, according to Al-Rasheed, is a product of the writers' continuous efforts in challenging the patriarchal norms and religious traditions: "[T] he new young Saudi woman novelist is focused on this world: her body, desires, career aspirations, and personal advancement...These heroines are living bundles of passions and desires, whose satisfaction is described in great detail in this fiction" (Al-Rasheed, 2013, p. 218). Significantly, the Kingdom's Vision 2030 which introduces lots of social reforms and promises much freedom, has raised the young female writers' contributions and increased their participation. The novels of these young writers like Fairouz Shabana's Searching myself (2018), Rehab Saad's Thousand Women in my Body (2019) and Malak Alageli's When Awareness is Pierced (2019) reflect the active participation of women in building contemporary identity of Saudi woman and provide an opportunity to discuss social realities, women's education and national identity in the light of the better governance declared by the Crown Prince in 2016. This rich participation of women novelists lends a new perspective and a strategic means of expressing new reality in history; allowing them to share their vision and ideas on national identity.

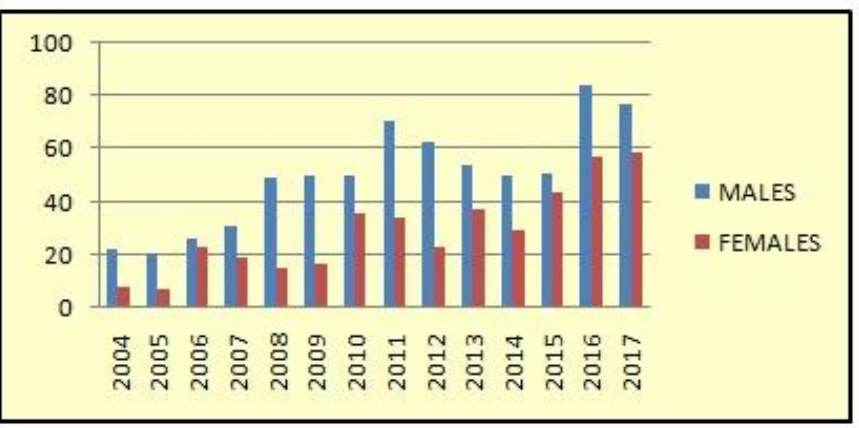

Fig. 2. The publication of Saudi men and women novelists 2004-2017. 
Through tracing the consistent focus of Saudi writers on national identity, it is important to note that the political context in Saudi Arabia has given a noticeable support for writers to reflect on national identity in narrative writing of each era. As has been noted, writers of the new millennium showed a remarkable interest on national identity, defining it and digging for its roots, a fact that allowed them to come out of the shadows. This generation of writers usually represents characters as middle class, intellectuals, and social reformists whose nationalist zeal enables them to liberate the readers from tribal and religious constrains. These writers not only succeed in enhancing social changes and taking part in creating the national identity with postmodern characteristics, but also achieve a significant progress both in quantitative and qualitative terms. These writers have gained widespread readership and indeed appreciation for some of reasons, including the focus on national identity, the representing several social issues the society was not ready to discuss and the exposure of many contradictions within classic Saudi identity.

\section{IMPLICATION FOR WRITERS’ ASPIRATION}

The Vision has set forth the roadmap for the young writers to represent their present and future concerns in freedom and contribute to the country's leading position in the Middle East: "Our geographic, cultural, social, demographic and economic advantages have enabled us to take a leading position in the world...Our status will enable us to build on our leading role as the heart of Arab and Islamic worlds" (Vision 2030, 2016). These plans envisioned future atmosphere will be better for all Saudi writers and talented individuals who experienced less freedom before the Vision 2030. Certainly, for narrative writers such as Abdo Khal and Umaimah Alkhamees this was a "transformation from regional to international" for Saudi novel that "lives its golden era and has the largest readership in both Gulf countries and the Arab world" (Sollywood. 2019). According to Alkhamees, "Saudi readers and intellectuals have become producers of all forms of narrative work in the four years after the unveiling of Vision 2030 instead of being consumers" (2019). In fact, as the two authors emphasize, Saudi writers have been used to hearing promises of social reforms from the $70+$ generation who however well-meaning are almost out of touch with the way that young writers think. Therefore, in order for awareness of the social and cultural aspects of the Vision to reach a larger circle of young writers, these aspects should be promoted on social media in order to reach the vast majority of young writers. Vision 2030, according to Nader Alenazi, is multi-dimensional as it encompasses all aspects of national culture and identity and stresses the importance of assisting young people to participate their thoughts and ideas

After a long-waited decision for encouraging young writers of narrative work in the Kingdom, the Vision 2030 came to ensure full support for talented writers, authors, publishers and artists. It is a roadmap and a platform through which narrative work will flourish. Intellectuals and writers believe that Prince Mohammed bin Salman's vision will provide autonomous space and contribute greatly to the development of national culture...The Vision 2030 announces its support for cultural associations which will facilitate achieving the cultural aspect of the Vision. If this is done, national literature will see a 'quantum leap' across all genres. (2016)

The Kingdom's Vision 2030 has posited several points on national identity that Saudi novelists have been expecting from the social and cultural perspectives of the vision. Nadia Alfawzan, fiction writer, says "the Visions provides a special opportunity for narrative writers...Fiction and nonfiction publication in the country has become huge; it is a positive phenomenon that that reflects a determined public ambition towards returning the country to its position among the nations" (2020). Saudi writers perceive these cultural changes as a potential opportunity for lifting restrictions on representing issues in national literature. These changes in the "socio-political reality of the Kingdom" have been reflected "in the radical transformation of the Saudi novel" and have "also profoundly affected both Saudi national identity and cultural production in the Kingdom” (Algahtani, 2016, p. 28). The socio-cultural reforms implemented after the Vision agreeably have both a positive impact for literature. Whichever way some critics consider the reforms as political, narrative writers find it a fact that they and their literary thoughts are of strong relevance.

\section{IDENTITY IN FICTION: RELIGION AND IDENTITY}

Al-Mohaimeed's Where Pigeons Don't Fly (2014) is a critique on the negative influence of religious extremism and radicalism on youth and how religious fundamentalists use and manipulate religion to achieve personal goals. This is clearly seen in the story of Suleiman, who was born in Buraida. Suleiman was a bit 'troubled,' due to his conservative and overbearing father, Ali, and the superstitious family in which he was born. In his teenage, Suleiman was recruited by a fundamentalist group and was caught by the police while participating in handing out religious pamphlets which were critical of the Saudi leadership in August 1979 just two months before the Siege of the Grand Mosque. He landed in jail for four years. After being released, and due to the stigma of the jail, he left Buraida for Riyadh where he lived until his death.

Suleiman is not only a victim of wrong teachings of religious fundamentalists but also a victim of his family. Because he was born in a night in which there was a lunar eclipse, Suleiman was considered as an ill omen. He was treated poorly by his father and sometimes his father wished his death: “Ali [Suleiman's father] was miserable, distraught 
and full of foreboding. An eclipse of the moon as a child entered the world! For a newborn to arrive accompanied by the wrath of God was terrifying; the baby's whole life and future was in doubt" (Al-Mohaimeed, 2014, p. 17). Throughout his life, Sueliman hears his father say: "I said he was defective from the day he was born" (p. 17). Suleiman's "childhood became filled with injustice and misfortune and he lived all his days with a sense of guilt for what had befallen his family" ( $p$. 17). When Mohammed, Suleiman's younger brother, was infected by measles and passed away, Suleiman's father says: "If death let me choose between them, I would ask he take the bird of ill omen" (p. 18). Suleiman, feeling unworthy and being hated, wants to prove himself. So he joins the fundamentalists just to tell his father "Here I am! Here I am. The one you mocked and whose fate you saw in the moon!" (p. 20). Suleiman joins the terrorist group because he finds acceptance, belonging, and a sense of purpose which he lacks at home.

Where Pigeons is a warning especially for youngsters against religious extremism and radicalism. Youth are the primary target of voluntary and forced recruitment by extremist and terrorist groups. There are different reasons why youngsters are favored targets of recruitment such as poverty, ignorance and weak family ties which can create a fertile ground for the terrorist ideas. The religious clerics have been able to manipulate the youth mentality through the break of traditional identities, nullifying the national identity and patriotism and violation of human rights. Thus, those affected adversely by their teachings are turned from good citizens into time bombs. The push of the young men into medieval practices by religious sheiks poses a challenge to communal harmony and perpetrates the backwardness of their societies. Youngsters are filled with wrong ideas such as western policy in the Middle East is unjust, some government are wrong etc. and are radicalized by the flawed interpretations of Quranic teachings. Where Pigeons denounces Islamist extremism and fundamentalism and exposes the looming threat of extremist religious groups and the deviant religious discourse.

The religious groups that we meet in Mohaimeed's fictional world are working against the larger national and political agendas. The setting of the novel in a crucial moment in the history of Saudi Arabia, the rise of militant religious fundamentalism in the 1970s, and the re-narration of the siege of the Grand Mosque in Mecca in 1979 which is a seminal event in modern history of KSA, highlights the serious threat that these groups pose to the stability and legitimacy of Saudi regime. For this reason, Suleiman, once a member of these groups, was afraid that his son, Fahd, may join extremist groups "his fear that his son might become embroiled in the activities of extremist groups and that he might not stop at distributing pamphlets in the court of the Grand Mosque, as his adolescent father had done back in the dying days of Ramadan in August 1979, but take up arms or strap an explosive belt to his body" (p. 14). In his diary, which Fahd reads many years later after the death of his father, Suleiman writes: "You keep it safe after I am gone and remember that the ultimate destiny of the political parties and religious groups that vex the government is extinction, failure and psychological torment. While your contemporaries are seizing their opportunities and succeeding, you will have wasted the best years of your youth chasing after lost dreams" (p. 17). This is the message of AlMohaimeed himself in the novel to all youth of Saudi Arabia: they have to work for their future and be cautious of any ideology that may lead to their destruction.

Al-Mohaimeed's critique of religious extremism and fundamentalism highly corresponds with 2030 Saudi vision announced on 25 April 2015 by the Crown Prince Mohammed bin Salman, who was very clear about the need for change. Referring to the conservative changes that occurred after the Grand Mosque of Mecca siege, he stated that "the post 1979 era was over" and that

Saudi Arabia was not like this prior to 1979. Saudi Arabia and the entire region had the awakening project spread after 79'... We only want to go back to what we were, the moderate Islam that is open to the world, open to all the religions. $70 \%$ of the Saudi people are less than 30 years old, and quite frankly, we will not waste 30 years of our lives in dealing with extremist ideas. We will destroy them today. We want to live a normal life, a life that translates our moderate religion, our good customs... I believe that we will eradicate the rest of extremism very soon. (Wayne, 2018, p. 566)

He, further, spoke about restoring the true, more tolerant and more open Islam: the 'Islam of love not fear.' His speech was followed by work. A new authority was established to scrutinize hadiths, many clerics who espoused radicalism were dismissed. The government has also established centers: The Global Center for Combating Extremist Ideology and the Ideological Warfare Center to combat, expose and refute extremist (Solomon 2020, p. 181). Other changes include lifting the ban on cinemas, limiting the powers of the Virtue Police, lifting the ban on women driving and many others (Solomon, 2020, p. 181).

The two-identity sets which the novel addresses are the religious/Islamic and the national; both are understood as collective identities. That is, our understanding of identities in relation to others with whom we feel some allegiance. They are often used to differentiate ourselves from others. The novel demonstrates that one's alignment with a religious community or group makes one lose his sense of national loyalty or solidarity and the outcome is an identity with fractioned loyalties. Of course, these two identities are contrived and imaginary categories. They are strongly related to each other in the Saudi community and repeatedly present in many Saudi literary discourses particularly since 2000 and the events of $9 / 11$. If loyalty is the overarching feature of one's love for home, the 'center', as examined by Jacques Derrida, seems to 
have been decentred by the Saudi religious groups. They have directed loyalty not to the State as an abode for all but to the group. The novel provides a perspective for understanding the relation between the two identities and how the national identity has been overcome or eclipsed by the religious one. This provides the rationale for the exploration of the identities as represented in this text as well as an approach to explore whether the integration of religious and national identities in the novel is encouraged or discouraged.

Actually this study is proposed to understand the religious and national identities in Saudi novel and to examine how such identities emerge, converge and compete with one another. As a fact both national identity and religious identity are imagined and constructed; they are not natural and 'real'. Religious identity is a socially constructed identity. The identification of oneself as Muslim and more precisely Salafi, Sufi, Ikhwan, Muslim Brothers etc. allows membership and divides the community into closed groups with private political and social agendas and goals. The perspective that membership in those identity categories is productive and serves certain agendas is significant for this study.

Further, these religious groups have never explained to youngsters what it means to be 'proper' citizens, or taught them notions about nationhood and patriotism because they have been busy with preparation to for receiving Al-Mahdi or for fighting the governments. The question to be answered in this study is whether the religious identity might now be overlaid by the national renaissance and the concerns of the Saudi nation. It is hoped that Saudi youth as readers of these fictions will be able to develop an entirely new identity which is national by nature and which can compete with other identities and able to add a new understanding to other identities particularly the religious one because, as the centre of Islam, it is impossible to entirely separate the two in the Saudi society.

Fiction like Where Pigeons contributes to the formation of the national identity in modern Saudi. Stuart Hall (1996) discusses the importance of myth and narrative in developing national identity. He contends that it is in discursive representation of a identity that people learn how to become national and social actors. According to him: "National cultures construct identities by producing meanings about 'the nation' with which we can identify; these are contained in the stories which are told about it, memories which connect its present with its past, and images which are constructed of it. (p. 612). Hall claims that identities, being unfixed, are both incidentally and intentionally produced and created. They are subject to historical, institutional and political factors. What people experience highly influences the way they position themselves in the world (p.48). Thus, the teachings of the religious clerics and sheiks are influential on youngsters. This is what the religious groups exploit; they target youngsters and then reshape their identities and loyalties in a way that serves their agendas.
The novel reveals the tremendous influence of social forces and surroundings on the formation of identity and the transformation of one's character. Actually, identity is flexible and contingent. It is constantly under revision, and shifts according to a range of political, social and historical circumstances. Two examples can make this point clear: the first is Suleiman and the second is his daughter, Lulua. Suleiman was born in a joyless and superstitious family and a religious and conservative society and the result is he becomes a terrorist landing in jail. But when he leaves his village in Burayda and goes to Riyadh, he meets Abu Essam, the Palestinian-Jordanian accountant and gets acquainted with him. Abu Essam helps him and shows him how to develop himself and so he attends night classes and then university and becomes a general manager. This shows how family and friends can be a source of success or a source of failure. However, his daughter goes the opposite side. Lulua is a clear example of the power that these extremist groups can do on the youth. When her father is alive she has a dream of becoming a television presenter or a singer. But after the death of her father and the coming of her uncle to their home as her step father, everything changes in her life. Commenting on the change of his sister, Fahd Says:

Everything has changed so much. Our life has turned completely upside down. Lulua's childhood has been brought to an end; now she's a woman who wants only to be a good, pious little wife when once she dreamed of being a television presenter... Now she dreams of being a corpse washer, or one of those female preachers, doing the rounds of gatherings and get-togethers and delivering Islamic lectures, telling women to fear God and the torment of the grave, to set aside the sinful habits of those who have fallen by the way, to invite them to organise themselves. Sometimes I imagine her joining some militant Islamist group. If the terrorists changed the way they worked and brought in women as partners and operatives, they'd be enthusiastic fighters for the cause, strapping on bomb belts to blow away anything they regarded as sinful and become martyrs, flying straight to Paradise. (Al-Mohaimeed, 2014, p. 82)

Where Pigeons describes the imminent formation of national identity and the factors that influence such formation. The novel is Al-Mohaimeed's contribution to the creation of a national consciousness in Saudi and to the promotion of a future reality in which all Saudis are part of the same nation and share the same destiny. The novel speaks of people's worries and the kind of state they dream of. Novels such Where Pigeons demonstrate the importance of narrative in the political and social change initiated by the 2030 vision. The Saudi novelists have extensively used fiction to promote the future of the Kingdom. It expresses the wishes of many Saudi to become a strong nation looking for the future and held back 
by the outdated thoughts of religious clerics. Al-Mohaimeed does not denounce or attack religion itself; rather he is against the misuse of religion and the multiplicity of allegiances and loyalties.

Al-Mohaimeed's novel celebrates personal freedom which is a crucial matter for building one's identity. The novel opens Fahd, with the protagonist, on a train in England going to Great Yarmouth. This 'green and pleasant land' is the place he has chosen as a refuge in his self-exile. The year is 2007. As the story unfolds, the readers come to know why Fahd is living in exile rather than living at home 'where the pigeons don't fly.' At home, in spite of the ubiquitous and intrusive eyes of the Virtue Police, Fahd, a young, liberal man, manages to rendezvous with a couple of girlfriends in rented rooms or in his car. Once, when Fahd and his girlfriend Tarfah are at Starbucks café to have coffee together, they were caught and are detained by the Virtue Police simply because they are drinking coffee together in public while they are unmarried. With the help of his uncle Saleh, he is released. After the death of his parents and the suffocating vigilance of the Virtue Police, Fahd decides to leave the country. No doubt that one of the main catalysts for Fahd's exile is lack of personal freedom in Saudi. One morning he and his beloved Turfa meet in a coffee shop in the families section of the shop. But to his astonishment they are arrested by the Religious Police known in Saudi as "Committee for the Promotion of Virtue and the Prevention of Vice." Expressing his sadness over the power that the guardians use to control others' lives, he says: "I, too, have known happiness for fleeting moments. But in this country they're too sharp to let joy bloom unchecked. The guardians of twisted virtue, the guardians of the imprisoned breeze, leapt to pluck out my joy in its first year of life. I wonder, why do these severe and grim-faced men invade the precious privacy you have with your beloved?" (p. 29).

Where Pigeons is a critique of the invasive religious police or Virtue Police, "severe and grim-faced men" who are "too sharp to let joy bloom unchecked," (p. 29) and their black beards, whom the readers meet throughout the novel patrolling the streets, and spying in coffee shops, malls, restaurants etc. for secret trysts. The Kingdom has a religious policemen called The Committee for the Promotion of Virtue and the Prevention of Vice. Other names such as mutawa, mutaween are also used to refer to members of the committee. The task of this group is to "monitor public behavior to enforce strict adherence to conservative Islamic norms" (Cordesman, 2009, p. 119). This committee is organized under the regime in conjunction with Islamic Ulema (clergy). But they are known for their ubiquitous and intrusive eyes and are understood to overuse "their authority with both Saudi and expatriates alike by undue harassment of both men and women in public places and trespassing into private homes" (p. 286). They can intimidate abuse and detain Saudi citizens and also foreigners of both sexes. However, Al-Mohaimeed believes that the religious police has never done anything that help the internal security of the Kingdom. They've never paid a good efforts in in reducing the practices of the extremists and "defending the core values of Islam against extremism" or any "role in defending religious values while aiding modernization and reform (p. 288). They, as Cordesman says, "have been a "gentler and kinder" Taliban (p. 296).

\section{MODERNITY AND IDENTITY}

While Al-Mohaimeed's Where Pigeons tackles the destructive power of misinterpreted religion on societies and its negative impact on national identity, Al-Atiq's Life on Hold demonstrates the coming of a new mechanism of national identity which is shaped by modernity. It signifies the importance of the past, history and traditions for cultivating and nurturing the national identity among youth. Al-Atiq's Life on Hold (2012) critiques the project of modernity for denouncing the traditional and placing the foreign cultures as the center of Saudi civilization as well as the materialistic impulse that accompanied it. It focuses on memory and rehabilitation of the tradition and the old which has been destroyed by modern and emergent cultures and their impact on the identity formation of Saudis. The loss of the past is a loss of the nation itself as Isabel Caldeira writes that the memory of any nation "is an artifact nurtured by rituals and traditions" (2016, p. 75). This cultural and economic transformation has resulted in a fast development of the postoil Saudi Arabia. This economic boom and overall development have given a convincing case to discuss the cultural break that is referred to or reflected in Saudi novelists' rendition of national identity and alienation which invaded the Saudi society due to modernization and demonstrates that alienation is the outcome of loss of identity.

Life on Hold centers on Khaled, a young fellow, who was born in the city of Riyadh, where he spends his childhood. At that time, Riyadh is being rapidly transformed due to the oil boom and, like tens of Saudi families, Khaled's family is uprooted and moves to the new Riyadh where Khaled gets his "dream job, but it turned into monotonous drudgery" (p. 3) and where "days are all much the same, bringing nothing new" (p. 8). Life in the new Riyadh is different. Khaled has "a deep sense of alienation" (p. 12). Nothing has a meaning to him and to defeat the boredom that he feels, he goes "through a youthful incoherent form of rebellion," but recognizes as - a feeble effort to feel something different and to "distance himself from the monotony of their neighborhood"- and finds it just replacing one form of unsatisfying boredom with another (p. 75). In his search for meaning in this vast and boring world, Khaled also makes an attempt in writing and instead of writing he stares at the blank page: "Whiteness seeking the secret of meaning" which he cannot provide ( $\mathrm{p}$. 44).

Khaled feels isolated in his society and from himself as well. He expresses this sense of unbelonging through his reluctance to form any ties with his colleagues at work or neighbors. What Khaled should understand is that there is no return to the past, there is no going back to live in the way he used to. What this means is a dialectic of dispossession as a constitutive 
element of modernity, a fact the Khaled and his people have to learn to live with. The feeling of unbelonging creates nostalgia and reverence for cultural manifestations of the past and because Khaled is unable to understand the social and cultural surroundings, he is unable to locate his place within the new cultural and social context. He loses interest in life and days become monotonous: "The days were much the same in this city, which did not know if it was pious or decadent" (p. 12). This aimlessness is not exclusive to Khaled alone as many of his colleagues are also lost like him. He feels that everyone was also running "but they didn't know where they were going. Young men chased breathlessly after business with no guarantee of success" (p. 96). It seems that everybody is running but the directions are blurred and the destination is uncertain. Khaled ponders the loss of his self, hoping to the awakening of a perspective inside him which may render a meaning to his own existence and the chaotic world in which he finds himself. He struggles first to find himself and second to establish an equilibrium that balances man not only with himself but also with his fellow man. The self-destructive confusion and the psychological ambivalence make him succumb to his whims and the mounting temptation of his friends and starts a new life of wine and women.

The resultant impact of this economic boom and wealth is that life which was once based upon habit and tradition has become terribly mechanical and ritualistic. Khaled's habitual handling of his situation and life is mechanistic and superficial. He tries drinking, debauchery and prostitution as possible cures for his boredom and loneliness. Khaled's apparent disintegration is the result of his lack of will and internal strength to reject the habit and the tradition and to confront the reality - the recognition that his life is at loss and that between tradition and modernity he himself opted for neither but swaying in-between the two not knowing the meaning or the right choice. The central theme of Life on Hold is undoubtedly the existential struggle of Khaled - his idealism and alienation; the narrative pointedly centers on his loss of and search for identity, his true self. The Khaled's story is a story of the loss of modern man and his alienation-his continuous struggle to conquer alienation and achieve some forms of stable identity with the object-world.

The novelist explores the Saudi society through Khaled, the protagonist, whose life, though monotonous, is rich with memories which bridge the gap between the old pauperized Najd and the consumerism that follows the oil boom. This movement of the Saudi society is symbolized by the family's move from the mud streets of the old Riyadh to the new villa in the new suburbs of the city. In this sense, Life on Hold is a compelling novel about the metamorphosis and contradictions of contemporary Riyadh, the "city of masks," and Saudi Arabia in general (p. 2). The new Riyadh city is totally different from the old city that Khaled knew as a child. He finds that "Riyadh had changed into something else, something like the sterile concrete house that they had recently moved into and that they called a villa" (p. 12). The new city is "like a pressure cooker about to explode" (p. 12). It is a city where
"Real neighborhoods are dead, real society is dead, real people are dead" (p. 32). It is a place where everything's gone to pieces. Relationships between people have gone to torn pieces and similarly work-place has gone to torn pieces "and family relationships have gone to pieces. We're sunk in huge religious, political, and economic contradictions. Real neighborhoods are dead, real society is dead, real people are dead, and we can no longer pull ourselves together again to get out of this giant mess" (p. 32). Expressing his astonishment with the change in the Saudi community, Khaled says: "Thus the winds of change swept them away: silence, monotony, and boredom replaced the hustle and bustle and the visits with neighbors and relatives, not just because the new suburbs were so far apart, but because people's lives had changed, not on the inside but on the outside" (p. 96). However, Khaled knows that it is an empty change as he found that Riyadh became a hive of activities that does not produce anything useful things and a city "without the most basic elements of real life. Everyone was constantly running but they didn't know where they were going" (p. 96). It is a journey from a close-knit community living in mud huts to new and concrete villas where people are sealed into loss and alienation.

The novel demonstrates the coming of a new mechanism of national identity which is shaped by modernity. Identity is not a passive entity; it is determined by many external factors and influences and individuals, in forging their self-identities, are affected by the social and global influences which have dire consequences and implications in shaping their identities. Saudis are not different. The novel shows how the Saudis' identity is transformed by modernity inaugurated by capitalism. Writers such as Al-Atiq feel the need to question and challenge modern rationalities that have changed not only Saudis' life but also their culture, perceptions and imaginaries. In their humanist inquiry, these writers attempt to investigate into the social contradictions and injustices, and understand these metamorphoses so that they may find a way to resist this cultural and social dispossession; they also may choose to actively revive traditions in order to give back to their communities the lost sense and feeling of belonging and identity.

Al-Atiq is of the opinion that Saudi identity is in danger of globalization and modernity and that, due to these rapid changes, the Saudi culture will be lost together with their identity and that they should preserved their old traditions along with their identity, an identity uncontaminated by modernistic and global concepts and images. For him, modernity contributes to the disenchantment of the society through isolation and alienation. Though it enchants people through its richness and technologies, people who were born before this boom feel a nostalgic yearning for the old days especially to family gatherings, simplicity of life and sense of belonging.

The novel is set in the 1970s, a crucial period in the history of Saudi Arabia during which Saudi Arabia witnessed an economic boom that changed the Saudi society forever. New 
desires, dreams and fears entered the lives of Saudi people, entirely altering their sense of longings and perceptions, and triggering new imaginaries and beliefs. People started running for materialistic gains and competing to acquire new products to show that they are civilized. This development is characterized, besides the economic boom; by new technologies such new forms of transportation, and information transmission including satellites, and computer networks, which changed people perception and thinking. Moreover, the growing flow of people of various origins, religious and cultural backgrounds and political loyalties to Saudi Arabia have changed the Saudi cultural landscape and turned the ethnically, homogeneous state into a multiethnic and multicultural society. This and other factors have brought new dimensions to the making of national identities in Saudi Arabia. So, when dealing with modernity and its effect on the Saudi community, we have to consider the fluid, multi-layered identities of the contemporary global world. This modernity which sprung from the encounter with alien cultures, mores and religions is the outcome of 'traveling cultures' to use James Clifford's words. Roots which are always used as a predominant metaphor for traditions and culture are replaced by Gilles Deleuze and Félix Guattari's "rhizome" (2013, p. 3). Hence, Saudi writers such as Al-Atiq write against these notions of universalism and globalization. They address in a critical and a creative manner the dangers that Saudi identity encounters and what are the possible ways to protect it. These writers are prone to rehabilitating and reviving traditional values and practices. Their writing is a resistance to the dispossession of the Saudi community's collective identity. They are aware of the danger of the fragmentation of Saudi identities in the contemporary modern world, and hence their intervention highly contributes to a sense of solidarity and coherence often looked for in the past.

In Life on Hold, Al-Atiq deals sensitively with Saudis' struggle to find a foothold in the modern world. Deeply involved in Saudis' quest for order and identity, he makes these issues central to his novel. He is attempting to help young generations of Saudis identify with their own cultural heritage by giving them fictional but unmistakably familiar landscapes and by promoting the national aspects of their culture and by warning against losing oneself completely in 'imported' or 'borrowed' cultures. This economic boom and the indulgence in consumerism will disconnect the coming Saudi generation from their past; they will no longer be able to identify with their lost cultural heritage and therefore lose their national identity. As Mohan (2004) writes:

The social identity of people is rooted in their culture while at the individual level, it is determined by personal achievements. In order to experience a 'Wholeness,' it is necessary to fuse the individual and the social consciousness. However, the paradox of the modern predicament lies in the fact that owing to the fragmentation of the societies, the affinity that was once felt between the two has now been broken. (p. 47)

This explains the fragmentation of the Saudi society and the alienation that its subjects feel. Finally, Al-Atiq introduces a much more pessimistic view of life. As a narrative of estrangement, Life on Hold summons forth a point of selfawareness which Edward Engelberg describes as "a moment of reckoning, a turning back to survey what has been left behind, a synchronic confrontation with one's memory-chamber-with the past $(1989$, p. 3). Narratives such as Life on Hold, usually depicting times of transition, are "about people caught at precisely the moment when their old lives no longer suffice and their new lives seem as yet unrealizable" (Engelberg, $1989,124)$.

\section{CONCLUSION}

Vision 2030 is an ambitious project of social and cultural transformation of Saudi society aiming to promote national identity through social, educational and cultural means. The study finds that the construction of contemporary Saudi national identity requires considerable focus on promoting scientific research related to national literature. The implementation of the Vision 2030 in Northern Border University has successfully started implementing literary facets for attracting the students' attention to the importance of national literature. The study finds that national novel has a big concern in informing social constructs of national identity through social and cultural themes and comprehensive representations of national issues.

This study finds that the ways in which Saudi novelists interrogate the national identity issue shared by 2030 vision and national novel address the archetypal Saudi identity in three ways: first, that the construction of national identity requires much cultural openness with the world; second, that construction of Saudi national identity needs exclusion of otherness; and third, that national identity depends on the rich history of two historical regions - Najd and Hijaz - that binds identity to a unified territory. Further, the study recommends that national literature should be introduced to all the departments of literature in order to give visibility to issues that are at the core of 2030 vision's social and cultural aspect such as life style, appearance behaviours, attitudes, accepting differences and willingness to work and volunteer.

\section{ACKNOWLEDGEMENT}

The authors extend their appreciation to the Deputyship for Research \& Innovation, Ministry of Education in Saudi Arabia for funding this research work through the project number "IF_2020_8989". 
[1] K. T. Aboalshamat, "Awareness of, beliefs about, practices of, and barriers to teledentistry among dental students and the implications for Saudi Arabia Vision 2030 and coronavirus pandemic," J Int Soc Prevent Communit Dent, vol. 10, no. 4, pp. 431-437, Aug. 2020.

[2] M. Akeel. (2017, November 07). After 30 years in a coma, the real Saudi 'awakening' begins now. [Online]. Available: https://www.arabnews.com/node/1189856

[3] F. Al-Atiq, Life on Hold. (J. Wright, Trans.), Cairo and New York: The American University in Cairo Press, 2012.

[4] N. Alenazi. (2016, May 04). Intellectuals: Writing and Publishing houses are our need. [Online]. Available: https://www.okaz.com.sa/article/1055659

[5] N. Alfawzan. (2020, Oct. 2020). Saudi Novel amongst world's bestsellers. [Online]. Available: https://cutt.ly/Ijtb NAS

[6] N. Algahtani, "Defying convention: Saudi women writers and the shift from periphery to Centre," Women's Studies International Forum, vol. 59, pp. 26-31, 2016, https://doi.org/10.1016/j.wsif.2016.09.002

[7] M. Alharthi, Social Transformations in the Saudi Novel: Ibrahim Al-Nassir as A Case Study," Ph.D. Dissertation. The University Of Leeds, 2015 [Online]. Available: Https://Core.Ac.Uk/Download/Pdf/42605578.Pdf

[8] Y. Al-Mohaimeed, Where Pigeons Don't Fly. (R. Moger, Trans.). Doha: Blooms Burt, Qatar Foundation Publishing, 2014.

[9] M. Al-Rasheed, Contesting the Saudi State: Islamic Voices from a New Generations. Cambridge: Cambridge University Press, 2007.

[10] M. Al-Rasheed, A Most Masculine State: Gender, Politics, and Religion in Saudi Arabia. Cambridge: Cambridge University Press, 2013.

[11] M. Altwaiji \& M Telha, "Yemeni Narrative and Society: Socio-political Issues in Dammaj's The Hostage," Journal of History Culture and Art Research, vol. 9 no. 3, pp. 317324, Sept. 2020. DOI: http://dx.doi.org/10.7596/ taksad.v9i3.2497

[12] M. Altwaiji, "History of Saudi Folklore and Factors that Shaped it," Trames: journal of the humanities and social sciences, vol. 21, no. 71/66, pp.161-171, 2017. DOI: 10.3176/tr.2017. 2.0

[13] M. Altwaiji, "Issues Related to Arab Folklore with reference to Laila Halaby's Once in a Promised Land, a post 9/11 novel," International Journal of Humanities and Cultural Studies, vol. 2, no. 4, pp. 114-123, March 2016.

[14] M. Bar-Maoz, "On Religion and the Politics of Security: How Religion's Involvement in Domestic Politics Affects National Securitymaking," The Review of Faith \& International Affairs, vol. 16, no. 2, pp. 36-49, 2018. DOI: $\underline{10.1080 / 15570274.2018 .1469822}$

[15] I. Caldeira, "Memory is of the Future: Tradition and Modernity in Contemporary Novels of Africa and the African Diaspora," e-cadernos CES, vol. 26no. 26, pp. 6891, 2016. DOI: 10.4000/eces.2126

[16] M. Chulov. (2017, Oct. 24). I will return Saudi Arabia to moderate Islam, says crown prince. [Online]. Available: https://www.theguardian.com/world/2017/oct/24/i-willreturn-saudi-arabia-moderate-islam-crown-prince

[17] J. A. Cochran, "The Rise in Power of Crown Prince Mohammed bin Salman," Digest of Middle East Studies, vol. 28no. 2, pp. 369-385, 2019.

[18] A. H. Cordesman, Saudi Arabia Enters the Twenty-First Century. USA: Greenwood Publishing Group, 2003.

[19] A. H. Cordesman, Saudi Arabia: National Security in a Troubled Region. Washington: ABC-CLIO, LLC, 2009.

[20] G. Deleuze \& F. Guattari, A Thousand Plateaus: Capitalism and Schizophrenia. (B. Massumi, Trans.). London and New York: Bloomsbury Academic, 2013.

[21] E. Engelberg, Elegiac Fictions: The Motif of the Unlived Life. USA: The Pennsylvania State University Press, 1989.

[22] S. Hall \& P. DuGay, (Eds.). Questions of cultural identity. London: Sage, 1996.

[23] S. Hall, "The question of Cultural Identity," in Modernity: An Introduction to Modern Societies, S. Hall et al., Ed. Massachusetts: Blackwell Publishing, 1996, pp.595-634.

[24] F. Jawadi, J. Nabila \& C Abdoulkarim, "Toward a new deal for Saudi Arabia: oil or Islamic stock market investment?," Applied Economics, vol. 50, no. 59, pp. 6355-6363, 2018. DOI: 10.1080/00036846.2018.1486018

[25] M. Kanie, "Young Saudi Women Novelists: Protesting Clericalism, Religious Fanaticism and Patriarchal Gender Order," Journal of Arabian Studies, vol. 7, no. 2, pp. 283299, 2017. DOI: 10.1080/21534764.2017.1499227

[26] C. R. Mohan, Postcolonial Situation in the Novels of V.S. Naipaul. New Delhi: Atlantic Publishers and Distributors, 2004. 
[27] L. Schwartz, et al, Barriers to the board dissemination of creative works in the Arab world. Santa Monica: Rand, 2009.

[28] A. Shboul, "Gendered space and dynamics in Saudi Arabian cities: Riyadh and Dammam in Turki al-Hamad's trilogy," Literature \& Aesthetics, vol. 17, no. 1, pp. 203223, 2007.

[29] Sidiya, F. (2010, Aug. 01). Ban on Al-Gosaibi's books lifted. [Online]. Available: https://www.arabnews.com/no $\underline{\text { de } / 351697}$

[30] Sollywood. (2019, April 06). Saudi novel and Cinema in the light of Vision 2030. [Online]. Available: http://sollywood.com.sa/2019/04/06/

[31] H. Solomon \& A. Tausch, Islamism, Crisis and Democratization Implications of the World Values Survey for the Muslim World. Switzerland: Springer, 2020.

[32] M. C. Thompson, "Saudi Vision 2030': A Viable Response to Youth Aspirations and Concerns?," Asian Affairs, vol. 48, no. 2, pp. 205-221, 2017. DOI: $10.1080 / 03068374.2017 .131359$

[33] M. C. Thompson, "Societal transformation, public opinion and Saudi youth: views from an academic elite," Middle Eastern Studies, vol. 53, no. 5, pp. 834857, 2017. DOI: $10.1080 / 00263206.2017 .1304918$

[34] Vision 2030. Kingdom of Saudi Arabia. [Online]. Available: https://cutt.ly/3ziw7Zd

[35] C. Wayne, Mastering Yourself, How to Align Your Life with Your True Calling \& Reach Your Full Potential. Florida: The Corey Wayne Companies, Inc., 2018.

\section{Creative Commons Attribution License 4.0 (Attribution 4.0 International, CC BY 4.0)}

This article is published under the terms of the Creative Commons Attribution License 4.0

https://creativecommons.org/licenses/by/4.0/deed.en US 